\title{
URGENSI USHUL FIQH BAGI PERMASALAHAN FIQH YANG DINAMIS
}

\author{
Auffah Yumni \\ Dosen Prodi Pendidikan Guru Madrasah Ibtidaiyah Universitas Islam Negeri Sumatera Utara \\ Email : aufahyumni@gmail.com
}

\begin{abstract}
Abstrak : Syariat Islam, ruang lingkupnya mencakup segala aspek kehidupan manusia. Sejak periode awal sejarah Islam, perilaku kehidupan kaum muslimin dalam keseluruhan aspeknya telah diatur oleh hukum Islam. Aturan-aturan ini, pada esensinya, bersifat religius. Oleh karena itu, dalam pembinaan dan pengembangannya, selalu diupayakan berdasarkan kepada al-Qur'an, sebagai wahyu Illahi yang terakhir, yang pengaplikasiannya untuk sebagian besar dicontohkan dan dioperasionalkan oleh sunnah Rasulullah saw. Dalam perkembangan selanjutnya, ini kemudian dipahami oleh umat Islam melalui metode ijtihad untuk dapat mengantisipasi setiap perkembangan yang timbul dalam masyarakat. Ijtihad inilah yang kemudian melahirkan fiqh. Keterbutuhan fiqh terhadap ushul fiqh senantiasa tidak akan pernah padam, karena masyarakat senantiasa bergerak dinamis sesuai situasi sosial, politik dan kebudayaanya sudah berbeda dan Ushul fiqh merupakan timbangan atau ketentuan untuk istinbath hukum

Kata Kunci : Ushul Fiqh, Ijtihad
\end{abstract}

\section{Pendahuluan}

Manusia dengan potensi akal sekaligus nafsunya menjadikan senantiasa memiliki kreasi sekaligus ambisi. Selain itu sebagai makhluk sosial senantiasa berinteraksi dengan manusia lain. Akibatnnya terjadi perkembangan yang pesat dan beragam dari interaksi-interkasi tersebut. Selanjutnya muncul beragam persoalan baru yang belum pernah ada di masa sebelumnya. Pada saat yang sama, agar manusia tetap memperoleh kerahmatan dan keberkahan dalam hidupnya maka harus tetap dituntun dan dipandu dengan aturan-aturan Islam. Persoalannya kitab-kitab Fiqih klasik yang telah dituliskan oleh para ulama pada zamannya 
belum membahas persoalan kontemporer yang muncul saat ini. Sementara ayatayat al-Quran dan hadits-hadist Nabi Saw juga tidak secara sharih (jelas) menjawab persoalan kontemporer tersebut. Karena itulah diperlukan ijtihad, yaitu usaha maksimal dari seorang mujtahid untuk menggali hukum syariat dari dalildalil syariat atas masalah kontemporer tersebut.

Ijtihad adalah satu-satunya metode syar'i untuk menentukan status hukum atas suatu perbuatan dan benda. Seorang Mujtahid haruslah memiliki kualifikasi dan kompetensi keilmuan tertentu sesuai dengen level status mujtahidnya. Di antara ilmu yang sangat berperan dalam proses ijtihad adalah ilmu Ushul Fiqih. Ia mutlak dikuasai bagi seorang mujtahid. Ushul Fiqih adalah metode/jalan yang harus ditempuh bagi seorang mujtahid agar ijtihadnya benar. Itulah di antara hikmah mengapa Allah mengganjar dua pahala bagi seorang mujtahid yang benar ijtihadnya, karena ia telah menempuh metode dan proses ijtihad yang benar dan hasilnya juga benar, sedang mujtahid yang salah hasil ijtihadnya tetap mendapat satu pahala karena meski hasil ijtihadnya keliru namun ia telah menempuh metode/jalan ijtihad yang benar. Disinilah arti penting ilmu Ushul Fiqih.

Ushul Fiqih adalah warisan kekayaan intelektual Islam yang sangat berharga. Hanya saja ketika warisan ini ditinggalkan umat sebagai akibat tidak diimplementasikannya Islam dalam kancah kehidupan, maka terjadikan kemunduran berpikir di tubuh umat Islam. Dampak selanjutnya mereka dengan sadar atau tidak telah mengadopsi hukum dan aturan hidup warisan penjajah.

Disinilah, diperlukan usaha keras memecahkan kejumudan berpikir akibat telah lamanya ditinggalkan metode berpikir yang berlandaskan pada Ushul Fiqih (ushuli).

\section{Pengertian Ushul Fiqh dan Cakupannya}

و أما أصول الفقه: Imam Abu Ishak As-Syirazi dalam Al-Luma’ menyebutkan Artinya, “Ushul fiqih ialah dalil-dalil penyusun fiqih, dan metode untuk sampai pada dalil tersebut secara global," (Lihat As-Syirazi dalam Al-Luma’ fî̀ Ushûlil Fiqh, Jakarta, Darul 
Kutub Al-Islamiyyah, 2010 M,: 6). Maksudnya adalah bahwa ushul fiqih merupakan seperangkat dalil-dalil atau kaidah-kaidah penyusunan hukum fiqih serta metode-metode yang mesti ditempuh agar kita bisa memanfaatkan sumbersumber hukum Islam untuk bisa memformulasikan sebuah hukum khususnya terkait sebuah persoalan kekinian. Kita juga bisa menengok pemaparan Imam Al-

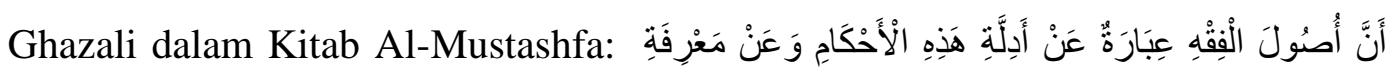

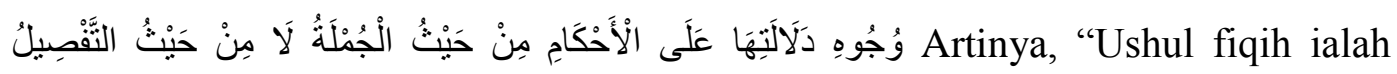
istilah untuk (seperangkat) dalil-dalil dari hukum-hukum syariat sekaligus pengetahuan tentang metode penunjukan dalilnya atas hukum-hukum syariat secara global, bukan terperinci," (Lihat Imam Al-Ghazali, Al-Mustashfa, Beirut, Darul Kutub Al-Ilmiyyah, 2002 M, : 5)

Secara garis besar, menurut Muhammad Husain Abdullah cakupan pembahasan Ushul Fiqih ada empat, yaitu:

1. Pembahasan tentang dalil dan yang berkaitan dengannya. Mencakup apa saja yang dapat dijadikan sebagai dalil, baik yang disepakati maupun yang masih diperdebatkan.

2. Pembahasan hukum dan yang berkaitan dengannya. Mencakup pembahasan pengertian hukum syariat, jenis-jenis hukum syariat, tujuan (maqashid) hukum syariat, rukun-rukun hukum mencakup al hâkim (siapa yang berhak menjadi sumber hukum), mahkum fih, dan mahkum 'alaih.

3. Makna lafadz (dalâlah alfâzh) baik yang ada dalam al Quran maupun as sunnah. Mencakup beberapa point yaitu:

a. makna lafaz dari sisi kejelasan dan kesamarannya. Dari sisi kejelasannya dibagi menjadi:al muhkam, al mufassar, an nash, dan az-zhahir. Dari sisi kesamarannya dibagi menjadi: al khafi, al musykil, al muhmal, dan al mutasyabih

b. makna lafaz dari sisi makna-maknanya seperti dalalah isyarah, dalalah ibarah, dan mafhum mukhalafah

c. makna lafaz dari sisi cakupannya seperti al 'âm dan al khâs, al mutlak dan al muqayyad 
d. makna lafaz dari sisi redaksi dan maksud tuntutan, mencakup al amr dan konsekuensinya serta an nahyu dan konsekuensinya

4. Ijtihad dan Taklid. Pembahasan terkait makna ijtihad, hukum ijtihad, jenis-jenis mujtahid dan syarat-syaratnya. Termasuk juga pembahasan tentang makna taklid, hukum taklid dan jenis-jenisnya(Muhammad Husain Abdullah, al Wadhih fi Ushul al Fiqh,: 20)

\section{Urgensi Ushul Fiqh dan Fiqih yang Dinamis}

Sebagaimana kita ketahui bahwa ilmu urgensitas ushul fiqh amat dirasakan dalam menangkap "pesan-pesan" Tuhan terutama yang berhubungan dengan amaliyah sehari-hari, hubungan antar makhluq, dan bukan hanya pada masalah aqidah (teologi). Manusia dengan potensi akal yang diberikan oleh Allah SWT, akan menemukan/mengkreasi hal-hal baru. Banyak hal-hal yang pada masa Rasulullah SAW masih hidup belum ada, ternyata hari ini terjadi, inilah yang dimaksud dengan masalah kontemporer. Tentu saja umat Islam memerlukan jawaban konkrit terkait dengan permasalahan hukum yang sifatnya kontemporer artinyakasus atau peristiwa masa kini yang belum terdapat penjelasannya secara tegas dalam al Quran dan as Sunnah serta belum dibahasa status hukumnya olah para ulama di masa lalu (klasik).

Satu-satunya metode yang diakui syari'at untuk menjawab persoalan yang hendak dicari status hukumnya adalah ijtihad, karena metode inilah yang disetujui oleh Nabi Saw saat berdialog dengan Mu'adz bin Jabal saat akan diutus ke Yaman sebagai wali atau hakim bagi penduduk Yaman. Ijtihad menurut ulama Ushul didefinisikan dengan :

استفراغ الوسع في طلب الظن بشئ من الاحكام الثرعية على وجه يحس من النفس العجز عن المزيد فيه Mengerahkan segenap kemampuan dalam mencari dugaan terhadap salah satu hukum syara' sampai batas dimana seorang mujtahid merasa tidak mampu lagi melakukan lebih dari itu.( Al Amidi, al Ihkam fi Ushul al Ahkam, juz IV, : 162) 
Dikatakan "mencari dugaan" karena hukum-hukum qath'i yang dinyatakan di dalam nash tidak memerlukan ijtihad. Dikatakan "atas salah satu hukum syariat" karena ijtihad tidak dilakukan dalam perkara akidah dan pengindraan. Definisi ini juga sekaligus menegaskan bahwa produk ijtihad merupakan hukum syara'. Dia memang Fiqih, namun Fiqih itu sendiri bagian dari syariat Islam. berusaha membedakan Fiqih dengan Syariat dari sisi qath'i dan zhani sejatinya bertentangan dengan definisi ini dan definisi Fiqih itu sendiri. Dikatakan "dalam bentuk dimana seorang mujtahid merasa tidak mampu lagi melakukan lebih dari itu" karena ijtihad dari orang yang lalai dan malas, sementara dia masih memungkinkan untuk menggunakan kemampuannya lebih tinggi lagi tidak terkategori ijtihad.

Ijtihad hukumnya fardhu kifayah. Tidak boleh terjadi kevakuman ijtihad dalam satu masa, jika terjadi kevakuman maka kaum muslimin semuanya berdosa, kecuali mereka yang mengupayakan adanya satu mujtahid atau lebih.(Atha Ibnu Khalil, Taisir Wushûl ilal Ushûl Dirâsâtun fî Ushûl al Fiqh,: 290)

Mengapa bisa demikian?. Setidaknya karena dua alasan:

1. Banyak masalah-masalah baru yang tidak ada nash-nya dalam Al-Qur`an dan As-Sunnah secara tegas. Misalnya :kloning, bayi tabung, dll.

2. Manusia wajib terikat dengan hukum syara' dalam segala perbuatannya, termasuk dalam masalah-masalah baru. Dalil-dalil wajibnya terikat dengan hukum syara' sangatlah banyak, di antaranya: QS 5:49; QS 4:65, dll.

Ijtihad bagi yang mampu melakukannya hukumnya wajib berdasarkan kaidah maa laa yatimmul wajibu illa bihi fahuwa wajib, (kewajiban yang tak terlaksana kecuali dgn sesuatu, maka sesuatu itu menjadi wajib pula hukumnya). Sebab tanpa ijtihad tak mungkin seseorang terikat dengan hukum syara' pada masalah-masalah baru.( Atha Ibnu Khalil,: 290)

Sumber utama ijtihad adalah al Quran dan as Sunnah. Keduanya, menurut Imam al-Ghazali (w. $505 \mathrm{H}$ ), bagaikan pohon yang senantiasa berbuah. Buahnya sangat bermanfaat dan dibutuhkan manusia. Namun produktivitas pohon tersebut tidak ada artinya jika bisa dipetik. Bahkan, bisa jadi buah pohon tersebut tidak 
pernah bisa dinikmati, selain hanya dilihat oleh semua orang yang ada di bawah pohon berbuah lebat tersebut. Disinilah maka sangat diperlukan kehadiran orang yang mampu memetik buah tersebut. Dialah orang yang akan memetik dan menghadirkan ke hadapan orang yang ingin menikmatinya. Pemetik itu tidak lain adalah mujtahid.

Hanya saja sang pemetik tidak sanggup memetik buah tersebut jika tidak ada alat yang dapat digunakan untuk memetik buah tersebut. Alat itu adalah Ushul Fiqih.( Al Ghazali, al Mustashfa fi 'Ilm al-Ushul,: 7)

Karena itu, adanya alat dan pemetik buah tersebut sama-sama pentingnya. Dari sini kita dapat memahami berapa sangat pentingnya peranan Ushul Fiqih dalam menjawab persoalan-persoalan kontemporer yang belum ada status hukumnya dalam al Quran dan as Sunnah serta kitab-kitab para ulama terdahulu.

Semakin jelas lagi perang Ushul Fiqih dalam proses ijtihad untuk menggali hukum jika ditinjau dari prosedur/proses ijtihad. Syaikh 'Atha Ibnu Khalil juga menjelaskan tentang prosedur atau langkah-langkah ijtihad dilakukan dalam tiga langkah yaitu : ('Atha Ibnu Khalil, Taisir Wushûl ...., : 264-265)

1. Memahami fakta masalah yang akan dihukumi

Pada langkah ini seorang mujtahid wajib mengkaji fakta-fakta terkait kasus atau peristiwa atau bahkan penomena yang hendak dicari status hukumnya. Semakin lengkap informasi atau fakta yang dikumpulkan maka gambaran terhadap fakta yang akan dihukumi juga semakin komprehensif. Pada langkah ini seorang mujtahid dapat bertanya dengan pihak-pihak yang ahli di bidangnya. Sebagai contoh fakta Kloning (klonasi) adalah teknik membuat keturunan dengan kode genetik yang sama dengan induknya pada makhluk hidup tertentu baik berupa tumbuhan, hewan, maupun manusia. Kloning manusia adalah teknik membuat keturunan dengan kode genetik yang sama dengan induknya yang berupa manusia. Hal ini dapat dilakukan dengan cara mengambil sel tubuh (sel somatik) dari tubuh manusia, kemudian diambil inti selnya (nukleusnya), dan selanjutnya ditanamkan pada sel telur (ovum) wanita 
yang telah dihilangkan inti selnya dengan suatu metode yang mirip dengan proses pembuahan atau inseminasi buatan. Dengan metode semacam itu, kloning manusia dilaksanakan dengan cara mengambil inti sel dari tubuh seseorang, lalu dimasukkan ke dalam sel telur yang diambil dari seorang perempuan. Lalu dengan bantuan cairan kimiawi khusus dan kejutan arus listrik, inti sel digabungkan dengan sel telur. Setelah proses penggabungan ini terjadi, sel telur yang telah bercampur dengan inti sel tersebut ditransfer ke dalam rahim seorang perempuan, agar dapat memperbanyak diri, berkembang, berdiferensiasi, dan berubah menjadi janin sempurna. Setelah itu keturunan yang dihasilkan dapat dilahirkan secara alami. Keturunan ini akan berkode genetik sama dengan induknya, yakni orang yang menjadi sumber inti sel tubuh yang telah ditanamkan pada sel telur perempuan(Abdul Qadim Zallum, Hukmu al Syar'i fi al Istinsakh,: 5)

2. Mengkaji nash-nash syara' yang terkait denganmasalah yang hendak dicari hukumnya.

Pada langkah ini seorang mujtahid mencari dalil-dali yang relevan sesuai dengan manhaj Ushul Fiqih yang dia adopsi. Misalkan ia hanya membatasi dalil hanya pada dalil-dali yang disepakati (al Quran, as Sunnah, Ijma' sahabat, dan Qiyas) maka ia hanya akan mencari dalil yang relevan dengan kasus dari sumber tersebut saja. Pada langkah ini semakin banyak dalil yang relevan dengan masalah yang dapat dikumpulkan semakin baik agar tidak terjatuh pada pengabaian dalil. Sebagai contoh tentang kloning, dalil-dalil yang dapat digunakan adalah dalil terkait proses terciptanya manusia adalah suatu yang alami, sebagaimana firman Allah:

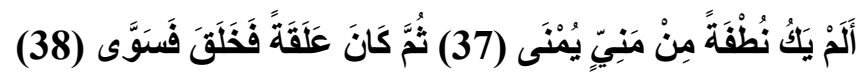

"Bukankah dia dahulu setetes mani yang ditumpahkan (ke dalam rahim), kemudian mani itu menjadi segumpal darah, lalu Allah menciptakannya, dan menyempurnakannya." (QS. Al Qiyaamah : 37-38) 
Proses pembuahan secara alami melibatkan pihak laki-laki dan perempuan, dalam hal ini Allah berfirman:

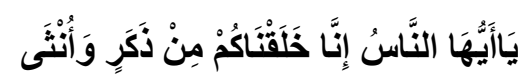

"Hai manusia, sesunguhnya Kami menciptakan kalian dari seorang lakilaki dan seorang perempuan." (QS. Al Hujuraat : 13)

Serta dalil bahwa Islam sangat menjaga kejelasan nasab. Diriwayatkan dari Ibnu 'Abbas RA, yang mengatakan bahwa Rasulullah SAW telah bersabda :

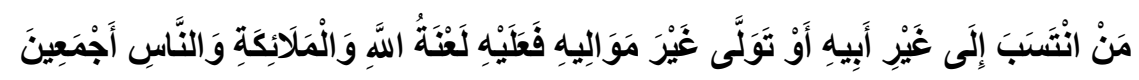

"Siapa saja yang menghubungkan nasab kepada orang yang bukan ayahnya, atau (seorang budak) bertuan (loyal/taat) kepada selain tuannya, maka dia akan mendapat laknat dari Allah, para malaikat, dan seluruh manusia." (HR. Ibnu Majah)

3. Mengistinbath hukum syara' dari nash-nash syara'.

Setelah dalil-dalil yang relevan dikumpulkan semua, langkah selanjutnya adalah mengoperasionalkan dalil-dalil tersebut dengan kaidahkaidah Ushul Fiqih yang ada. Baik dari sisi rajih marjuhnya, nashikh mansuhnya, mutlak-muqayyad, umum dan khususnya, mujmal dan mubayyannya dan seterusnya. Hingga akhirnya disimpulkan status hukum kasus yang dicari hukumnya. Dalam konteks hukum kloning pada manusia simpukan hukumnya haram karena tiga alasan, yaitu: proses penciptaan manusia tidak berjalan alami, dapat menghilangkan peran laki-laki karena seorang wanita dapat melahirkan bayi tanpa perlu pembuahan dari sperma laki-laki, dan karena berakibat pada kacaunya nasab.( Abdul Qadim Zallum, Hukmu al Syar'i fi al Istinsakh,: 5)

Seruan ditutupnya pintu ijtihad sejak akhir abad ke-4 H adalah seruan yang tepat/relevan pada saat itu. Karena hampir semua persoalan pada masa itu sudah terjawab dengan fatwa dari pada imam-imam mujtahid pada masa itu. Akhirnya fokus penulisan para ulama pada masa itu fokus pada syarah kitab-kitab imam mujtahid, terkadang bahkan syarah 
atas kitab syarah yang diistilahkan dengan hasyiyah, bahkan apa yang sudah disyarah diringkas lagi. Hal ini terus terjadi hingga abad ke-7 H. Dan kemunduran berpikir ini semakin menjadi-jadi dari abad ke-7 $\mathrm{H}$ hingga ke-13 H, yaitu ketika kaum muslimin tidak lagi menjadikan Islam sebagai aturan hidup mereka. Mereka akhirnya mengadopsi undangundang produk Barat, khususnya Inggris dan Prancis. Seperti di Turki sebagai pusat kekuasaan Islam yang mengadopsi UU Hukum Pidaan Negara Ustmani pada tahun 1857, UU Keuangan dan Perdagangan pada tahun 1859. Pada tahun 1870 membagi lembaga peradilan menjadi dua yaitu peradilan syariah (mahkamah syariah)dan pengadilan umum/sipil (mahkamah nizhamiyah)(Abdul Qadim Zallum, Konspirasi Barat Meruntuhkan Khilafah Islamiyah,: 36)

Hingga saat institusi yang selama ini menjadi penjaga dan pelaksana syariah di-ebolish oleh Mustafa Kemal atas dukungan Inggris, kaum muslimin tidak memberikan pembelaan yang optimal(Abdul Qadim Zallum, Konspirasi Barat Meruntuhkan Khilafah Islamiyah, hal.179) Kondisi umat Islam saat ini benar-benar dalam kondisi yang memprihatinkan, yaitu kondisi yang jauh dari Syariat karena sulitnya memberikan gambaran gambaran pelaksanaan Syariat yang komprehensif (kaffah).

Tidak diterapkannya Islam dalam kancah kehidupan menjadi faktor utama kemunduran berpikir. Umat kehilangan ghirah untuk terikat pada syariat Islam dalam setiap aktivitasnya. Mereka hanya merasa wajib terikat dengan syariat dalam bidang yang amat sempit seperti shalat, zakat, puasa, haji, nikah, talak, rujuk, waris, dsb. Namun cenderung kurang peduli terhadap kewajiban terikat terhadap aturan Islam dalam bidang politik, ekonomi, hukum, peradilan, sistem sanksi, politik luar negeri, pendidikan, sosial, budaya dan bidang bidang kehidupan yang lain.

Kondisi ini adalah gambaran dari pandangan sekularisme, pandangan hidup dari Barat yang memisahkan urusan agama dengan 
urusan kehidupan. Orang-orang yang terpapar paham sekular ini akan mengatakan "jangan campurkan urusan agama dengan politik, karena agama itu suci sedang politik itu kotor", "agama tidak tidak cocok untuk mengurus negara", dan ungkapan-ungkapan sejenis lainnya. Ruh sekularisme adalah kebebasan. Kebebasan ini kemudian menjalar dalam segala aspek. Kebebasan dalam bidang beragama menjelma menjadi sinkritisme agama, dalam bidang politik menjelma menjadi kebebasan manusia untuk membuat hukum dan undang-undang (demokrasi), dalam bidang ekonomi menjelma menjadi kapitalisme dan ambisi menguasai faktor-faktor ekonomi, di bidang pendidikan menjadi materialisme (orientasi materi, lembaga pendidikan dibuat mengikuti kebutuhan pasar), di bidang budaya menjadi paham hedonisme (serba boleh), dan seterusnya.

Atas dasar uraian di atas, tawaran solusi untuk mengembalikan semangat berpikir ushuli (kerangka pikir berdasarkan Ushul Fiqih) harus dimulai dari meng-install pemahaman umat tentang perkara yang paling mendasar yaitu akidah, bahwa manusia adalah hamba Allah, misi utamanya adalah beribadah kepada Allah, beribadah kepada Allah dalam segala aspek kehidupannya, tidak sepotong-sepotong seperti pemahaman kalangan sekularis. Wujudnya adalah keterikatan terhadap hukum-hukum syariat dalam segala bidang. Cara sederhananya adalah mengetahui status hukum atas setiap perbuatannya, termasuk dalam persoalan kontemporer.

Sementara keterikatannya terhadap syariat mewajibkannya untuk belajar kepada yang lebih 'âlim dan bagi mujtahid ada kewajiban untuk berijtihad. Seiring dengan semakin banyaknya persoalan kontemporer maka kebutuhan akan maujtahid juga semakin banyak. Dengan landasan seperti inilah seorang pengkaji ilmu semestinnya memiliki visi bahwa ia harus menjadi seorang mujtahid, selain motivasi bahwa seorang mujtahid meski hasil ijtihadnya keliru ia tetap mendapatkan pahala. Karena visi yang besar akan mendorong untuk berbuat lebih besar dan lebih 
bersemangat. Jadilah kajian-kajian bahasa arab, ulumul quran, ulumul hadis, tafsir, sirah, tarikh, Ushul Fiqih, Fiqih dan ilmu-ilmu syariah lainnya menjadi kajian-kajian yang menarik dan menggairahkan karena dikaitkan dengan visi besar untuk membangkitkan umat dengan metode berfikih sesuai kerangka ushul fiqh.

\section{Penutup}

Sebagaimana yang kita ketahui tujuan yang hendak dicapai dari ilmu Ushul al-Fiqh adalah untuk dapat menerapkan kaidah-kaidah terhadap dalil-dail syara' yang terinci agar sampai kepada hukum-hukum syara' yang bersifat amali, yang ditunjuk oleh dalil-dalil itu. Dengan kaidah ushul serta bahasannya itu dapat dipahami nash-nash syara' dan hukum yang terkandung di dalamnya. Demikian pula dapat dipahami secara baik dan tepat apa-apa yang dirumuskan ulama mujtahid dan bagaimana mereka sampai kepada rumusan itu.

Dengan demikian, apabila target dari ilmu ushul fiqih sebagaimana telah dijelaskan diatas, sedangkan pintu ijtihad telah tertutup sejak sekitar sepuluh abad yang lalu, dan manusian sejak saat itu sampai sekarang masih terikat dan berpegang teguh pada hukum-hukum fiqih yang tertulis dalam kitab-kitab madzhab fiqih, hal ini berarti dari ilmu ushul fiqih tidak tercapai.

Sesungguhnya pendapat mayoritas ulama menyatakan bahwa pintu ijtihad itu adalah berdasar dalil syara'. Hanya saja, ulama berpendapat demikian karena pertimbangan-pertimbangan yang telah dikemukakan diatas. Dengan demikian, bagi seseorang yang memenuhi syarat ijtihad, tidak ada halangan baginya untuk melaksanakan ijtihad. Karena tidak seorang pun berpendapat bahwa ijtihad itu mempunyai masa atau kurun tertentu dan terbatas sehingga bisa dikatakan waktunya sudah berakhir. Demikian juga tidak ada seorang ulama yang berpendapat bahwa ijtihad itu dilarang sama sekali. Oleh sebab itu, ijtihad kapan saja dapat dilakukan dan bisa kembali lagi sebagaimana di masa Aminat Al- 
Mujtahidin selama ada orang yang ahli dalam ber-ijtihad atau selama ada orang yang memenuhi syarat ber-ijtihad.(Rahmat Syafi'i, Ilmu Ushul Fiqih, hal. 43).

\section{Daftar Pustaka}

Abdul Qadim Zallum, Konspirasi Barat Meruntuhkan Khilafah Islamiyah,Bangil: al-Izzah, 2001

Abdul Qadim Zallum, Hukmu al Syar'i fi al Istinsakh, Beirut: Darul Ummah, 1997

Al Ghazali, al Mustashfa fi 'Ilm al-Ushul,Beirut: Darul Kutub al 'Ilmiyah, 1993 As-Syirazi dalam Al-Luma' fî̀ Ushûlil Fiqh, Jakarta, Darul Kutub AlIslamiyyah, $2010 \mathrm{M}$

Atha Ibnu Khalil, Taisir Wushûl ilal Ushûl Dirâsâtun fî̀ Ushûl al Fiqh.Beirut: Dâr al Ummah, 2000

Ilmu Ushul Fiqih, Bandung: Pustaka Setia, 2007 